\title{
Relevance of Good Corporate Governance and Financial Leverage on Firm Value
}

\author{
Putri Dwi Wahyuni \\ Lecturer of Accounting Department, Universitas Mercu Buana, Indonesia
}

\begin{abstract}
Firm value is a certain condition that has been achieved by the company as a result of trust in the community and investor perceptions of the level of success of the company. The implication of good corporate governance is one way to increase firm value. In addition, one of the company's funding sources came from debt. The smaller the debt in a company, the investors will be happy to provide funding because the company's profits will be used more as dividends and that will increase the value of the company. This study aims to analyze relevance of good corporate governance (institutional ownership, managerial ownership, the proportion of independent commissioners, the number of audit committees) and financial leverage on firm value. The population in the study is a manufacturing company with the number of samples according to the calculation of the Slovin formula carried out during 2016 - 2017 as many as 117 data. The results of this study indicate that the number of audit committees has a significant effect on firm value, while institutional ownership, managerial ownership, the proportion of independent commissioners and financial leverage have no significant effect on firm value
\end{abstract}

Keywords: mechanism good corporate governance, financial leverage, firm value

DOI: $10.7176 /$ RJFA/10-14-13

Publication date:July $31^{\text {st }} 2019$

\section{Introduction}

A company is established with the purpose to get profits and going concern for a long time by optimizing firm values. Firm values is the investor's perception of the company that can be measured through several aspects, one of which is the company's stock price because the current stock price reflects the investor's assessment of the company in the future and the investor's overall assessment of each equity owned. Firm value is very important because it can increase prosperity for shareholders so that the higher the stock price, the higher the value of the company. In addition, investors have the main objective to improve their welfare, namely by expecting the benefits obtained by buying or owning shares, namely capital gains and dividends (Mahfizatun, 2013).

In maximizing firm values, a conflict of interest between management and shareholders will emerge, usually called agency problem. A conflict of interest arises because of a different goal between the agency (management) and the principal (shareholders). The management prioritizes personal interests, whereas shareholders do not like the personal interests of the manager because what the manager does will increase costs for the company, causing a decrease in company profits and influencing stock prices thereby reducing the value of the company (Mutmainah, 2015).

Based on IDX Statistics (2017), manufacturing industry trade amounted to $51.94 \%$ consisting of basic industrial sectors amounting to $28.06 \%$, food and beverage sector at $23.11 \%$ and other industries at $7.08 \%$. This indicates that the company value of the manufacturing sector is relatively large and the level of public trust is high which is seen from the trading of its shares included in the first rank, followed by the financial sector at $40.52 \%$.

Firm value can be shown from the value of price to book value (PBV). According to Brigham and Houston (2013: $152), \mathrm{PBV}$ is a comparison between stock prices and the book value of a company, where the book value of a company is a ratio between total equity and the number of outstanding company shares. The higher PBV means the market believes in the company's prospects. Companies that operate well, generally have a PBV ratio reaching above one which indicates that the stock market value is greater than the book value.

One of the factors that influence company value is the implementation of Good Corporate Governance, which is a system (input, process, output) and a set of rules that regulate relationships between various stakeholders, especially in the narrow sense of the relationship between shareholders, board of commissioners, and board of directors for the achievement of company goals. The expected goal through the implementation of Good Corporate Governance is to maximize the value of the company for shareholders. This goal is achieved through the company's efforts to provide maximum performance, both financial performance and non-financial performance through aspects of fairness, transparency, accountability, and responsibility.

The Financial Services Authority (OJK) encourages the implementation of Good Corporate Governance by companies in Indonesia. According to the ASEAN Corporate Governance Scorecard (ACGS), Indonesia's ranking 
improved with Indonesia's issuers' scores in 2017 rising to 70.59 , from the 2015 state average at 62.88 . Despite the increase, Indonesia's position is still below the Philippines, which is in position 12, Thailand in position 6 , Malaysia in position 4 and Singapore in position 3. (ACGA, 2018).

According to Permanasari (2010) states that the magnitude of the level of ownership of financial institutions results in greater power and the drive to optimize the value of the company. The existence of share ownership by institutional investors, the monitoring process will run more effectively so that it can reduce managerial actions in terms of conducting earnings management so that it can harm the interests of certain parties (stakeholders). The existence of an independent board of commissioners is needed by the company to reduce the conflict of interest between management and shareholders. In order for the duties of the board of commissioners to run effectively, it is necessary to have an audit committee to assist the commissioners in seeking the performance of independent auditors to be transparent and accountable. Low leverage ratio indicates that the company does not use a lot of debt in funding the company's operations. The smaller the debt in a company, the investors will be happy to provide funding because the company's profits will be used more as dividends and that will increase the value of the company.

According to Fadjar (2013) the proportion of independent commissioners and leverage does not affect the value of the company. Furthermore, the research of Apriadi and Suardhika (2016) found that institutional share ownership has a positive effect on firm value. This study shows that with the increasing level of institutional ownership, the stronger the external supervision of the company. The existence of high institutional ownership will lead to an increase in more optimal supervision of the quality and continuity of the company to achieve company goals, namely optimizing the value of the company. The higher institutional ownership, the oversight effort will be greater by institutional investors so that opportunistic behavior of managers is hindered. Ararat et al. (2016) states that ownership structure does not affect company value (Tobin's Q proxy) with governance predictions only increases the company value by $8-10 \%$.

\section{Literature Review}

\subsection{Theory of Agency}

Jensen and Meckling (1976) define Agency theory as a relationship between an agent (management) and a Principal (company owner) who are bound in a contractual manner. The Principal assigns tasks to agents to provide services (services) for the benefit of the principal. Agency theory or also in literature called "contracting theory" is a theory originating from the theory of the company (theory of the firm) proposed by Ronald Coase (1937).

Agency relations can raise to problems when the parties concerned have different objectives. In the process of maximizing firm value, there will be a conflict of interest between managers and shareholders (company owners) which are often called agency problems. It is not uncommon for management, namely company managers, to have goals and other interests that conflict with the company's main objectives and often ignore the interests of shareholders. Good Corporate Governance is said to be able to create added value because by implementing Good Corporate Governance, it is expected that the company will have good performance so that it can create added value and increase the value of the company that can provide benefits to shareholders or company owners (Riana and Iskandar, 2017).

\subsection{Theory of Signalling}

Signal theory according to Spence (1973) states that companies with high performance use financial information to send signals to the market. Signaling theory explains how signals of success or failure of management (agent) are conveyed to the owner (principal).

Companies can increase company value by reducing information asymmetry. One way is to signal to outside parties in the form of reliable financial information and will reduce uncertainty about future prospects for the company. Based on signal theory, good quality companies will intentionally signal to the market, thus the market is expected to be able to distinguish between good and bad quality companies. In order for the signal to be effective, it must be captured by the market and perceived well and not easily imitated by poor quality companies (Wulandari and Wiksuana, 2017).

\subsection{Development of Hypothesis}

\section{Effect of Institutional Ownership on Firm Values}

Jensen and Meckling (1976) state that institutional ownership is one of the tools that can be used to reduce agency conflicts between managers and shareholders. Apriadi and Suardhika (2016) found that institutional share ownership has a positive effect on firm value. This study shows that the higher the level of institutional ownership, the stronger the external supervision of the company. The existence of high institutional ownership will lead to an increase in more optimal supervision of the quality and continuity of the company to achieve company goals, 
namely optimizing the value of the company. All of these will reduce agency risk and also increase firm value. Based on the description above, the first hypothesis to be tested in this study are:

\section{H1: Institutional ownership has a significant effect on firm value}

\section{Effect of Managerial Ownership on Firm Values}

Jensen and Meckling's (1976) study found that managerial ownership succeeded in becoming a mechanism to reduce agency problems by harmonizing the interests of managers and shareholders. Managerial ownership is share ownership owned by management such as a board of directors or board of commissioners. Managerial ownership in agency theory is one way that companies can do in an effort to reduce agency conflict. The existence of managerial share ownership is seen to be able to harmonize the potential differences in interests between management and shareholders so that the agency problem is assumed to be lost if a manager is also at the same time as an owner. The greater the proportion of management ownership in the company, the management tends to be more active in meeting the interests of shareholders, which in fact is itself (Sari and Riduwan 2013).

Based on the description above, the second hypothesis to be tested in this study are:

\section{H2: Managerial ownership has a significant effect on firm value}

\section{Effect of the Independent Commissioner Proportion on Firm Values}

From the perspective of agency theory, board of commissioners represent the main internal mechanism for overseeing opportunistic behavior of management so that it can help harmonize the interests of shareholders and managers (Jensen, 1993). Companies listed on the IDX are required to have independent commissioners provided that the number of independent commissioners is at least $30 \%$ of the total number of commissioners. The need for an independent board of commissioners in the company is to help plan the company's long-term strategy and periodically review the implementation of the strategy (Purwantini, 2011). The existence of independent commissioners is expected to increase the effectiveness of supervision and strive to improve the quality of financial statements. Good supervision will minimize fraudulent actions taken by management in financial reporting so that the quality of financial statements will be better and make investors believe in investing in the company, so that in general the company's stock price will be higher and the company's value will increase (Dewi and Nugrahandi, 2014) Based on the description above, the third hypothesis to be tested in this study are:

\section{H3: The proportion of independent commissioners has a significant effect on firm value}

\section{Effect Number of Audit Committees on Firm Values}

According to agency theory, the audit committee is considered as a liaison between shareholders and the board of commissioners with the management in handling control issues. The audit committee has an important and strategic role in terms of maintaining credibility for the financial report preparation process and creating an adequate supervision system for the company and good implementation of corporate governance (Fadjar, 2013). So as to give a positive signal to the shareholders. According to Syafitri, et al. (2018) states that audit committees affect the value of the company. The number of audit committee members in a company must be adjusted according to the complexity of the company while always paying attention to the element of effectiveness in the decisionmaking process so as to contribute to the company's value as well as the quality of financial statements. Based on the description above, the fourth hypothesis to be tested in this study are:

\section{H4: Number of audit committees has a significant effect on firm value}

\section{Effect of Financial Leverage on Firm Values}

Leverage is the ability of companies to use debt to maximize profits (Rizqia et al., 2013). In accordance with signaling theory, the use of debt as a funding decision on a company will provide a positive signal for investors. Mardiyati (2012) states that an increase in leverage can provide two kinds of signals, namely good news and good news. Increasing leverage shows good news if the increase reflects management's ability to increase value. Instead, it shows bad news if the manager increases leverage because he is forced and not for reasons of efficiency. Achmad and Amanah (2014) explained that the use of external funds would add to the company's income which would later be used for investment activities that were profitable for the company so as to give investors hope that the company's growth in the future would rise and the company's value would increase. Based on the description above, the fifth hypothesis to be tested in this study are:

\section{H5: Financial leverage has a significant effect on firm value}

\section{3. $\quad$ Research Method}

This study uses a quantitative descriptive causal method. This study was conducted to examine the effect of institutional ownership, managerial ownership, the proportion of independent commissioners, the number of audit committees and financial leverage on firm value. This study uses multiple linear regression tests. The population in this study are manufacturing companies listed on the Stock Exchange in 2016 - 2017. The total population is 
154 issuers. The sample in this study amounted to 61 issuers with a total of 122 data for 2 years using the Slovin method

Table 1

Variable Operationalization

\begin{tabular}{|c|c|c|c|}
\hline No. & Variable Name & Indicator & Scale \\
\hline 1. & Firm Value & $\begin{array}{l}\text { - Book Value per Share (BV): The figure of BV is derived by dividing the Total } \\
\text { Shareholders' Equity by number of issued shares. } \\
\text { - Price to Book Value (PBV) }=\frac{\text { Regular Closing Price }}{\text { BV }}\end{array}$ & Ratio \\
\hline 2. & $\begin{array}{l}\text { Institutional } \\
\text { Ownership }\end{array}$ & $\begin{array}{c}\text { (Share ownership by institutional parties / outstanding share) } \mathrm{x} \\
100 \%\end{array}$ & Ratio \\
\hline 3. & $\begin{array}{l}\text { Managerial } \\
\text { Ownership }\end{array}$ & $\begin{array}{l}\text { (Shares of the board of directors and commissioners / outstanding } \\
\text { share) } \times 100 \%\end{array}$ & Ratio \\
\hline 4. & $\begin{array}{l}\text { Independent } \\
\text { Commissioners }\end{array}$ & $\begin{array}{l}\text { (Independent board of commissioners / member of the board of } \\
\text { commissioners) } \times 100 \%\end{array}$ & Ratio \\
\hline 5. & Audit Committee & the number of audit committee members owned by the company & Ratio \\
\hline 6. & $\begin{array}{l}\text { Financial } \\
\text { Leverage }\end{array}$ & $\mathrm{DER}=($ Total Debt $/$ Equity $) \times 100 \%$ & Ratio \\
\hline
\end{tabular}

The regression model in this study is stated as follows:

$\mathrm{PBV}=\alpha+\beta 1 \mathrm{INST}+\beta 2 \mathrm{MANJ}+\beta 3$ COMM_IND $+\beta 4$ AUD $+\beta 5 \mathrm{LEV}+\mathrm{e}$

\section{Result and Discussion}

\subsection{Result Data Analysis}

Based on the results of normality test data using the Kolmogorov-Smirnov test, obtained by the KS value of 0.080 with a significant value of 0.064 . It can be concluded that this study has data that are normally distributed, multicollinearity test also has a tolerance value $>0.10$ or VIF less than 10 . This means that this study does not have a relationship between each independent variable. Based on the results of the Glejser test the Sig. (2-tailed) all variables independent $>0.05$ means that variables are free from heteroscedasticity problems. Autocorrelation test results have also shown that the value of durbin-waston is in the area between du and 4-du is $(1,7883<2,137$ $<2,212)$. So that this study is also free from the problem of autocorrelation. To find out the truth of the regression test, the coefficient of determination (Adjust $\mathrm{R}^{2}$ ) is done to find out whether all variables have jointly significant influence on the dependent variable in the F test. Adjust R2 in this regression model has a value of 0.069 which means that $6,9 \%$ of this regression model influenced by Institutional ownership, Managerial ownership, Proportion Independent Commissioners, Number of Audit Committee and Financial Leverage while 91,1\% are influenced by other variables not included in this study. The Adjust R test results can be seen in the following table:

Tabel 2

Model Summary

\begin{tabular}{|l|c|c|c|c|}
\hline Model & $\mathrm{R}$ & R Square & $\begin{array}{c}\text { Adjusted R } \\
\text { Square }\end{array}$ & $\begin{array}{c}\text { Std. Error of the } \\
\text { Estimate }\end{array}$ \\
\hline 1 & $0,331^{\mathrm{a}}$ & 0,109 & 0,069 & 1,01105 \\
\hline
\end{tabular}

a. Predictors: (Constant), Lev, Aud, Inst, Manj, Comm Ind

b. Dependent Variable: ln_PBV

Based on table 3 below, only the variable number of audit committees has a significant effect on firm value so that hypothesis 4 is accepted. whereas institutional ownership, managerial ownership, the proportion of independent commissioners and financial leverage have no significant effect on firm value. 
D.

\begin{tabular}{|c|c|c|c|c|c|c|}
\hline \multicolumn{7}{|c|}{$\begin{array}{c}\text { Tabel } 3 \\
\text { t Test }\end{array}$} \\
\hline \multirow{2}{*}{\multicolumn{2}{|c|}{ Model }} & \multicolumn{2}{|c|}{$\begin{array}{l}\text { Unstandardized } \\
\text { Coefficien }\end{array}$} & \multirow[b]{2}{*}{$\mathbf{t}$} & \multirow[b]{2}{*}{ Sig. } & \multirow{2}{*}{$\begin{array}{l}\text { Decision } \\
\text { Hypothesis }\end{array}$} \\
\hline & & $\mathrm{B}$ & Std. Error & & & \\
\hline & (Constant) & $-3,008$ & 1,172 & $-2,567$ & 0,012 & \\
\hline & Inst & 0,005 & 0,003 & 1,545 & 0,125 & Rejected \\
\hline & Manj & $-0,005$ & 0,007 & $-0,778$ & 0,439 & Rejected \\
\hline & Comm_Ind & 0,009 & 0,013 & 0,696 & 0,488 & Rejected \\
\hline & Aud & 0,977 & 0,301 & 3,244 & 0,002 & Accepted \\
\hline & Lev & $-0,001$ & 0,002 & $-0,613$ & 0,541 & Rejected \\
\hline
\end{tabular}

Based on the table above, it can be seen that the Beta value variables of institutional ownership, the proportion of independent commissioners and the number of audit committees have a positive relationship with firm value. Managerial ownership and financial leverage variables have a negative relationship with firm value.

\subsection{Discussion}

\section{Effect of Institutional Ownership on Firm Values}

Institutional ownership is the amount of wealth in the form of shares owned by institutions and blockholders (Fadhilah, 2014). To supervise manager behavior in decision making requires the role of institutional ownership to be more careful in decision making (Shleifer and Vishny, 1986). Jensen and Meckling (1976) state that institutional ownership is one of the tools that can be used to reduce agency conflicts between managers and shareholders. The results of this study contradict the research of Riana and Iskandar (2017); Apriadi and Suardhika (2016) who found that institutional share ownership has a positive effect on firm value. The higher level of institutional ownership has made the stronger the external supervision of the company so that it will trigger an increase in more optimal supervision of the quality and continuity of the company to achieve the company's goals, namely optimizing the value of the company. But this research is in line with Ararat et al. (2016); Sofiamira and Asandimitra (2017); Nugroho and Agustia (2017) state that institutional ownership does not affect the value of companies with predictions of governance, only increases the value of the company by $8-10 \%$. This can be caused by the average institutional ownership of the manufacturing sector issuers tend to be small at 35\% so that the level of supervision is less optimal and the value of the company created is not optimal.

\section{Effect of Managerial Ownership on Firm Values}

Jensen and Meckling's (1976) study found that managerial ownership succeeded in becoming a mechanism to reduce agency problems by harmonizing the interests of managers and shareholders.

Managerial ownership in agency theory is one way that companies can do in an effort to reduce agency conflict. The existence of managerial share ownership is seen to be able to harmonize the potential differences in interests between management and shareholders so that the agency problem is assumed to be lost if a manager is also at the same time as an owner.

This is contrary to the research of Sofiamira and Asandimitra (2017) stating managerial ownership has a positive effect on firm value, while institutional ownership does not affect the value of the company. This research is in line with the research conducted by Syafitri et al (2018) which states that managerial ownership does not have a significant effect on firm value. The number of managerial ownership is not able to reduce the conflict of interest in agency relationships because the average managerial ownership in manufacturing companies is very small at $5.9 \%$ so that the management who is actively involved in decision making is little and does not influence the outcome of the decision later.

\section{Effect of Proportion Independent Commissioner on Firm Values}

In the perspective of agency theory, board of commissioners represent the main internal mechanism for overseeing opportunistic behavior of management so that it can help harmonize the interests of shareholders and managers (Jensen, 1993). The increasing number of independent commissioners indicates that the independent commissioners carry out the function of supervision and coordination in the company as well. The implementation of good corporate governance can run well if supervision and coordination are carried out well so that in the end it can increase the value of the company. This research is contrary to the research of Syafitri et.al (2018) which states that independent board of commissioners has an influence on the value of the company. This is in line with the research of Riana and Iskandar (2017) that independent commissioners do not influence the value of the 
company. This shows that the monitoring function carried out by independent commissioners is not effective in reducing the oppurtinistic attitude taken by management. Debby et al. (2014) stated that independent commissioners did not have a significant effect on company value because independent board of commissioners was chosen at the general meeting of shareholders, aged over 50 years and retirees from ministries, soldiers or lecturers so that their ability to guide management creativity was less effective.

\section{Effect Number of Audit Committees on Firm Values}

The audit committee has an important and strategic role in terms of maintaining credibility in the process of preparing financial statements and creating an adequate monitoring system for the company and good implementation of corporate governance (Fadjar, 2013).

The results of this study are in line with the research conducted by Syafarina (2017); Syafitri et al (2018) which states that the number of audit committees has a significant effect on firm value. The number of audit committee members in a company must be adjusted according to the complexity of the company while always paying attention to the element of effectiveness in the decision-making process so as to contribute to the company's value as well as the quality of financial statements.

\section{Effect of Leverage on Firm Values}

In accordance with signaling theory, the use of debt as a funding decision on a company will provide a positive signal for investors. Mardiyati (2012) states that an increase in leverage can provide two kinds of signals, namely good news and good news. Increasing leverage shows good news if the increase reflects management's ability to increase value. Instead, it shows bad news if the manager increases leverage because he is forced and not for reasons of efficiency.

This is in line with Fadjar's (2013) study that the proportion of independent commissioners and leverage does not affect the value of the company. Obradovich and Gill (2013) revealed that a high level of leverage causes a decrease in firm value because of the high risk of bankruptcy and causes loss of investor confidence in the company The average leverage in manufacturing companies in this study is very large around $72.78 \%$ so that if the leverage ratio is high can cause financial difficulties that have an impact on the company's low value.

\section{Conclusion}

The results of this study indicate that only the variable number of audit committees has a significant effect on firm value, whereas institutional ownership, managerial ownership, the proportion of independent commissioners and financial leverage have no effect on firm value. Adjusted R-square value of 0.069 . This means that $6.90 \%$ of the variation in the number of Firm Values measured by PBV can be explained significantly by variations in Institutional Ownership, Managerial Ownership, Independent Commissioner, Audit Committee Size and Whereas Leverage $(100 \%-6.90 \%)=93.10 \%$ of the total Firm Value can be explained by other variables.

The suggestion in this study is to use other measurements for company value variables, for example PER, for good corporate governance mechanism variables plus other elements such as the effectiveness of independent commissioners, audit committees and board of directors in the form of meetings held in a year.

\section{References}

Apriadi,K.,Suardhika,M.S. (2016). Pengaruh Struktur Kepemilikan Saham, Struktur Modal dan Profitabilitas Pada Nilai Perusahaan. E-Jurnal Ekonomi dan Bisnis Universitas Udayana 5.2 : 201-218

Ararat. M, Black. B.S, Yurtoglu. B.B. (2016). The Effect of Corporate Governance on Firm Value and Profitability: Time-Series Evidence from Turkey. Emerging Markets Review. doi: 10.1016/j.ememar.2016.10.001

Brigham, Eugene, F, dan Joel,Houston. (2013). Dasar-dasar manajemen Keuangan, Salemba Empat, Jakarta

Debby, J.F, Mukhtaruddin, Yuniarti. E, Saputra. D, Abukosim. Good Corporate Governance, Company's Characeristics and Firm's Value : Empirical Study of Listed Banking on Indonesian Stock Exchange. GSTF Journal on Business Review (GBR) Vol. 3 (4

Fadjar O.P Siahaan. (2013). The Effect of Good Corporate Governance Mechanism, Leverage and Firm Size on Firm Value. Journal of Business Review (GBR) vol 2(4)

https://www.clsa.com/wp-content/uploads/2018/12/CG-Watch-2018-Short-version-181205-L.pdf. access date on 01 November 2018

https://www.idx.co.id/data-pasar/laporan-statistik/statistik/

Jensen, M.C., Meckling, W.H. (1976). Theory of the Firm: Managerial Behavior. Agency Cost and Ownership Structure. Journal of Financial Economics, 3(4), 305-360

Mahfizatun, N. (2013). Profitabilitas, Likuiditas dan Ukuran Perusahaan Pengaruhnya Terhadap Kebijakan 
Dividen dan Nilai Perusahaan Sektor Non Jasa. Jurnal Keuangan dan Bisnis Vol. 5(2)

Mardiyati, U. (2012). Pengaruh Kebijakan Dividen, Kebijakan Hutang dan Profitabilitas terhadap Nilai Perusahaan Manufaktur yang Terdaftar di Bursa Efek Indonesia (BEI) Periode 2005-2010. Jurnal Riset Manajemen Sains Indonesia (JRMSI). 3(1)

Mutmainah. (2015). Analisis Good Corporate Governance Terhadap Nilai Perusahaan. EKSIS Vol. X (2). Hal 181195

Nugroho, W.C. Agustia, D. (2017). Corporate Governanc, Tax Avoidance and Firm Value. AFEBI Accounting Review Vol. 2 (2). Hal 15 - 29

Obradovich, J., \& Gill, A. (2013). The Impact of Corporate Governance and Financial Leverage on the Value of American Firms. International Research Journal of Finance and Economics, ISSN 1450-2887 Issue 91, 1-14

Permanasari, W.I. (2010). Pengaruh kepemilikan manajemen, kepemilikan institusional, dan corporate social responsibility terhadap nilai perusahaan. E-journal undip

Purwantini, V. T,. (2011). Pengaruh Mekanisme Good Corporate Governance terhadap Nilai Perusahaan dan Kinerja Keuangan Perusahaan yang terdaftar di Bursa Efek Indonesia, Jurnal Ekonomi Bisnis dan Perbankan

Riana,.Iskandar,D. (2017). Pengaruh Ukuran Perusahaan, Corporate Governance dan Struktur Modal Terhadap Nilai Perusahaan. Profita Vol. 10 (3)

Sari, E. F. V., dan A. Riduwan. (2013). "Pengaruh corporate governance terhadap nilai perusahaan: Kualitas laba sebagai variabel intervening". Jurnal Ilmu dan Riset Akuntansi 1(1): 1-20

Shleifer, A., \& Vishny, R. W. (1986). Large shareholders and corporate control. Journal of political economy, 94(3, Part 1), 461-488

Sofiamira.N.A.,Asandimitra.N. (2017). Capital Expenditure, Leverage, Good Corporate Governance, Corporate Social Responsibility: Pengaruhnya Terhadap Nilai Perusahaan. Jurnal Ekonomi dan Bisnis Vol. 20 (2)

Spence, M. (1973). Job Market Signalling. Quarterly Journal of Economics. pp. 355-374

Syafitri.T, Nuzula.N.F, Nurlaily.F.( 2018). Pengaruh Good Corporate Governance Terhadap Nilai Perusahaan. Jurnal Administrasi Bisnis Vol 56 (1). Hal 118-126 